\title{
DINAMIKA LEMBAGA PENDIDIKAN TINGGI ISLAM DI INDONESIA
}

\author{
Amiruddin \\ Fakultas Tarbiyah dan Ilmu Keguruan IAIN Langsa \\ Jl. Meurandeh, Langsa, Aceh, 24411 \\ e-mail: emiyahya@gmail.com
}

\begin{abstract}
Abstrak: Tulisan ini berupaya menganalisis dinamika perkembangan Pendidikan Tinggi Islam di Indonesia dari perspektif sejarah. Penulis mengklaim bahwa Perguruan tinggi Islam pertama di Indonesia adalah STI (Sekolah Tinggi Islam) didirikan di Jakarta pada tahun 1945, yang tiga tahun kemudian ditransformasi menjadi UII (Universitas Islam Indonesia) di Yogyakarta. Pada tahun 1951, selanjutnya, pemerintah mendirikan PTAIN di Yogyakarta dengan menegerikan fakultas agama Islam pada UII. Disamping itu, pemerintah mendirikan ADIA (Akademi Dinas Ilmu Agama) di Jakarta pada tahun 1957. Hasil perkawinan kelembagaan antara PTAIN dan ADIA melahirkan IAIN atau al-Jamiah al-Islamiyah al-Hukumiyah didirikan pada tahun 1960 di Yogyakarta. Cabangcabang IAIN di daerah ditingkatkan statusnya oleh pemerintah pada tahun 1997 menjadi STAIN. Perkembangan paling signifikan terjadi pada tahun 2002 dimana beberapa IAIN dan STAIN dikonversi menjadi UIN. Penulis mengklaim bahwa format terakhir ini merupakan perkembangan paling sentral di era globalisasi dengan konsep integrasi ilmu.
\end{abstract}

\begin{abstract}
The Dynamics of Islamic Higher Education Institutions in Indonesia. This paper seeks to analyze the dynamics of the development of Islamic Higher Education in Indonesia from a historical perspective. The author claimed that the first Islamic College in Indonesia was the STI (Islamic High School) founded in Jakarta in 1945, which three years later was transformed into UII (Islamic University of Indonesia) in Yogyakarta. In 1951, furthermore, the government established PTAIN in Yogyakarta integrated in UII. In addition, the government established ADIA (Akademi Dinas Ilmu Agama) in Jakarta in 1957. The result of institutional marriage between PTAIN and ADIA gave birth to IAIN or al-Jamiah al-Islamiyah al-Hukumiyah was founded in 1960 in Yogyakarta. The IAIN branches in the region were upgraded by government in 1997 to become STAIN. The most significant developments occurred in 2002 where some IAIN and STAIN were converted to UIN. The author claims that this last format is the most central development in the era of globalization with the concept of science integration.
\end{abstract}

Kata Kunci: Indonesia, lembaga pendidikan tinggi, UIN, IAIN, STAIN 


\section{Pendahuluan}

Dalam konteks pendidikan, bahwa pendidikan Islam di Indonesia telah berlangsung ketika Islam hadir dan berkembang di Indonesia. Pendidikan Islam dalam bentuk kelembagaan belum terkonstruksi seperti pada era modern sekarang ini. Pada masa awal, proses sosialisasi dan penguatan ajaran Islam diekspresikan dalam bentuk pendidikan informal. Model transmisi ajaran Islam seperti ini telah berlangsung dalam kehidupan masyarakat Indonesia. Model pendidikan informal adalah model klasik-tradisional. Meskipun demikian, model pendidikan informal ini sangat efektif dan ajaran Islam dapat diserap dengan baik oleh masyarakat. Islam di Indonesia mendapat posisi yang stategis dan mempengaruhi kekuatan politik. Faktanya, Islam dapat menkonstruksi negara Islam dalam bentuk dinasti atau kerajaan-kerajaan di Indonesia, yang sebelumnya secara umum masyarakat Indonesia beragama Hindu dan Budha.

Kehadiran kolonial Belanda ke Indonesia dengan berbagai motif, di antaranya motif politik, ekonomi, doktrin kultural dan keagamaan. Belanda menjumpai masyarakat Indonesia telah menganut agama Islam dan hidup dalam nilai-nilai yang dibangun atas ajaran Islam. Pada sisi lain, lembaga-lembaga pendidikan Islam indegeneus sudah terbentuk, meskipun sangat sederhana, jika dibandingkan dengan sistem pendidikan modern, baik dari aspek kelembagaan, kurikulum, metode, dan manajemen. Masyarakat Indonesia memiliki perbedaan yang contras dengan Kolonial Belanda dalam hal agama (religi) dan budaya (culture). Oleh karena itu, Belanda membuat kebijakan diskiminatif kepada masyarakat pribumi dalam berbagai bidang, ${ }^{1}$ baik dari sisi ras, politik, ekonomi, agama maupun pendidikan. Umat Islam pada masa tersebut mengalami kesulitan dan hidup dalam iklim diskriminatif. Namun, semangat dan cita-cita umat Islam untuk mengembangkan pendidikan yang lebih maju dan berkualitas terus berdenyut dalam iklim kolonial. Lembaga-lembaga pendidikan Islam tumbuh subur di tengah kebijakan diskriminatif Belanda. Belanda tidak pasif dalam merespon gerakan umat Islam dan perkembangan pendidikan Islam, justeru Belanda aktif dengan membuat pendidikan sekuler sebagai anti tesis terhadap lembaga pendidikan Islam dan merancang regulasi untuk mengkarantina gerakan umat Islam dengan membuat Ordonansi yang sangat rigid dan tidak demokratis sebagai bangsa yang dikenal telah mempunyai peradaban modern.

Gema gerakan umat Islam kian bergelora di tengah era kolonial dan tidak pernah berhenti untuk berjuang meskipun pressure dari kolonial terus berlanjut. Sebab, umat Islam di Indonesia memiliki cita-cita mulia untuk generasi masa depan bangsa untuk memajukan pendidikan Islam di Indonesia. Misalnya, Dr. Satiman Wirjosandjoyo mengemukakan ide brilian tentang perlunya didirikan lembaga pendidikan tinggi, ide segar ini diungkapkan pada tahun 1930an. Kebutuhan sebuah perguruan tinggi Islam adalah untuk mengangkat harkat dan martabat

${ }^{1} \mathrm{Al}$ Rasyidin, "Islamic Organizations in North Sumatra: The Politics of Initial Establishment and Later Development," dalam Journal of Indonesian Islam, Vol. 10, 2016, p. 64. 
umat Islam di pemerintahan Hindia-Belanda yang terjajah. ${ }^{2}$ Akhirnya, pada tahun 1945 sebelum deklarasi kemerdekaan, atas bantuan kolonial Jepang di Jakarta, umat Islam mendirikan perguruan tinggi Islam pertama di Jakarta yang diberi nama STI (Sekolah Tinggi Islam), dan resmi dibuka pada tanggal 8 Juli 1945 di Jakarta.

Pertumbuhan dan perkembangan PTKIN (Perguruan Tinggi Kegamaan Islam Negeri) di Indonesia sebelum dan setelah merdeka terdapat suatu keunikan tersendiri dalam perjalanan sejarah bangsa Indonesia. STI pondasi awal PTKIN di Indonesia, dari STI kemudian muncul perguruan tinggi UII, PTAIN, ADIA, IAIN, STAIN dan UIN.

\section{Metode Penelitian}

Kajian terhadap dinamika lembaga pendidikan tinggi Islam ini menggunakan studi kepustakaan (library research) terhadap buku referensi, jurnal, arsip, dokumen, dan tulisantulisan lain yang memiliki relevansinya dengan judul yang diteliti. Dilihat dari aspek sifatnya penelitian ini adalah penelitian sejarah dan yang menjadi objeknya adalah dinamika lembaga pendidikan Tinggi Islam yang tumbuh dan berkembang di Indonesia sebelum dan sesudah Indonesia merdeka. Data-data yang ditemukan melalui penelusuran pada referensi yang berkaitan dengan penelitian. Kemudian data tersebut dipaparkan secara deskriptif analitik. Penelitian ini menggunakan metode penelitian kualitatif untuk menelusuri dan mengeksplorasi referensi. Dalam tradisi kualitatif, peneliti menggunakan diri mereka sendiri sebagai instrumen, mengikuti asumsi-asumsi kultural sekaligus mengikuti data. ${ }^{3}$ Dengan metode kualitatif data-data ditemukan secara alamiah dan kemudian dianalisis secara kritis dan memaparkan data seperti apa adanya.

\section{Hasil dan Pembahasan}

\section{Historisitas PTKIN di Indonesia}

Sejarah mencatat bahwa Islam telah suskes besar dalam melakukan misi dakwahnya di Nusantara dalam rentang waktu yang tidak terlalu lama. Kesuksesan ini lebih diakui lagi lantaran masuknya Islam ke wilayah kepulauan nusantara ini tanpa paksaan politik penguasa maupun peperangan, melainkan dengan cara damai melalui pendekatan kultural. Sementara penduduk Nusantara waktu itu telah memiliki agama yang kuat yakni Hindu dan Buddha. ${ }^{4}$

${ }^{2}$ Jajat Burhanuddin, "The Dutch Colonial Policy on Islam: Reading the Intellectual Journey of Snouck Hurgronje," dalam Al-Jami'ah: Journal of Islamic Studies, Vol. 52, 2014, p. 26.

${ }^{3}$ Julia Brannen, Memadu Metode Penelitian Kualitatif dan Kuantitatif (Yogyakarta: Fakultas Tarbiyah-Pustaka Pelajar, 1997) h. 11.

${ }^{4}$ Mujamil Qomar, Fajar Baru Islam Indonesia: Kajian Komprehensif Atas Sejarah dan Dinamika Intelektual Nusantara (Bandung: Mizan Pustaka, 2012) h. 59; Abdul Munir Mulkan, "Islamic Education 
Satu hal yang sangat menarik seperti apa yang digambarkan selama ini, yakni Islam memiliki karakteristik global, bisa diterima dalam setiap ruang dan waktu. Namun pada sisi lain, saat ia memasuki berbagai kawasan wilayah, karakteristik globalnya seolah-olah hilang melebur ke dalam berbagai kekuatan lokal yang dimasukinya. Suatu kecenderungan dimana Islam mengadaptasi terhadap kepentingan mereka. ${ }^{5}$ Masyarakat Indonesia sebelum Indonesia merdeka sudah beragama Islam. Kehidupan umat Islam di Indonesia (Nusantara) hidup dalam suasana ajaran Islam, baik budaya maupun dalam tradisi. Pola hidup yang diwujudkan dalam pemikiran, sikap dan perilakunya keseharian didasari pada ajaran Islam. Islam sebagai sebuah ajaran menjelma menjadi tatanan kehidupan yang mengatur semua perilaku masyarakat Indonesia.

Indonesia sebelum kemerdekaan berada dalam situasi sulit, di mana Indonesia di bawah pengaruh kolonial, baik Belanda maupun Jepang. Kondisi tersebut membuat umat Islam tidak mengalami kemajuan, sebab pemerintah kolonial tidak ingin umat Islam di Indonesia mengalami kemajuan. Segala upaya dan bentuk diskrimisasi terus dilakukan oleh pemerintah kolonial. Misalnya, pada masa pemerintahan Belanda, umat Islam (rakyat Indonesia) mendapat diskriminasi, baik dalam ranah agama, ras, politik, pendidikan dan maupun ekonomi. Kondisi tersebut telah memperlambat kemajuan umat Islam di Indonesia.

Pada sisi lain, bentuk ketidaksenangan Belanda terhadap umat Islam mencapai kemajuan. Belanda membuat peraturan-peraturan yang membuat gerakan umat Islam terkarantina. Pertama, pada tahun 1882, Pemerintah membentuk suatu badan khusus yang bertugas untuk mengawasi kehidupan beragama dan umat Islam yang mereka sebut dengan Priesterrden. Dari nasihat badan inilah pada tahun 1905 pemerintah Belanda mengeluarkan peraturan baru yang dikenal dengan nama Ordonansi Guru. Kedua, tahun 1925 pemerintah Belanda mengeluarkan Ordonansi Guru yang kedua, yang isinya mewajibkan bagi setiap guru agama untuk melaporkan diri pada pemerintah secara berkala. Kedua ordonansi ini dimaksudkan sebagai media pengontrol bagi pemerintah kolonial untuk mengawasi sepak terjang pada pengajar dan penganjur agama Islam di negara ini. Ketiga, pada tahun 1932, pemerintah Belanda mengeluarkan ordonansi Sekolah Liar (Wilde School Ordonansi). Ordonansi ini berisi kewenangan untuk memberantas dan menutup madrasah dan sekolah yang tidak ada izinnya atau sekolah yang memberikan pelajaran yang tidak disukai Belanda. ${ }^{6}$

Hasrat umat Islam untuk mendirikan pendidikan tinggi sudah dirintis sejak zaman kolonial Belanda. M. Natsir menulis dalam Capita Selekta, bahwa keinginan untuk mendirikan pendidikan tinggi Islam itu telah muncul di hati umat Islam. M. Natsir menyebutkan, bahwa Dr. Satiman telah menulis artikel dalam Pedoman Masyarakat nomor 15 membentangkan

And Da'wah Liberalization: Investigating Kiai Achmad Dachlan's Ideas," dalam Al-Jami'ah: Journal of Islamic Studies, Vol. 46, 2008, h. 402.

${ }^{5}$ Ajid Thohir, Studi Kawasan Dunia Islam Perspektif Etno-Linguistik dan Geo-Politik (Jakarta: Rajawali Pers, 2011) h. 1.

${ }^{6}$ Abuddin Nata, Sejarah Pendidikan Islam (Jakarta: Kencana, 2011), h. 285. 
cita-cita beliau yang mulia akan mendirikan satu sekolah tinggi Islam itu akan berpusat di tiga tempat, yakni Jakarta, Solo dan Surabaya. Di Jakarta akan diadakan sekolah tinggi sebagai bagian atas Sekolah Menengah Muhammadiyah (AMS) yang bersifat Westerch (kebaratan). Di Solo akan diadakan sekolah tinggi untuk mendidik mubalighin. Di Surabaya akan diadakan sekolah tinggi yang akan menerima orang-orang pesantren. Kendatipun yang diungkapkan ini masih dalam bentuk ide, akan tetapi semangat untuk mendirikan perguruan tinggi Islam itu telah muncul pada tahun 1930-an. ${ }^{7}$

Di samping itu, Muhammadiyah telah lama berniat untuk mendirikan perguruan tinggi (Universitas Muhammadiyah). Pada tahun 1936, dalam konggres seperempat abad Muhammdiyah di Jakarta, telah diputuskan akan mendirikan Universitas Muhammadiyah. Tetapi kemudian mendapat rintangan, karena pecahnya Perang Dunia ke II. ${ }^{8}$ Berdasarkan hal itu, dapat dimaklumi bahwa umat Islam sejak zaman kolonial Belanda telah memiliki cita-cita untuk mendirikan perguruan tinggi. Apalagi di kalangan pemerintah kolonial Belanda sudah lama berdirinya lembaga pendidikan tinggi, misalnya Sekolah Tinggi Tekhnik (Technische Hogesshool) didirikan tahun 1920 di Bandung, dan Sekolah Tinggi Hukum (Rechtskundige Hogeschool) didirikan tahun 1920 di Jakarta, dan Sekolah Tinggi Kedokteran (Geneeskundige Hogeschool) berdiri tahun 1927 di Jakarta. ${ }^{9}$

Mahmud Yunus ${ }^{10}$ menyampaikan bahwa Perguruan Tinggi yang pertama di Minangkabau, bahkan di seluruh Indonesia, ialah Sekolah Islam Tinggi, didirikan oleh persatuan Guru-Guru Agama Islam (PGAI) di Padang yang dipimpin oleh Mahmud Yunus. Sekolah Tinggi itu dibuka secara resmi pada tanggal 9 Desember tahun 1940, terdiri dari dua Fakultas yakni Fakultas Syariat (Agama) dan Fakultas Pendidikan dan Bahasa Arab. Sekolah Tinggi itu berjalan dengan lancar sampai tahun 1942. Tetapi sayang ketika Jepang masuk kota Padang (Maret 1942) dan memerintah Indonesia, maka Sekolah Islam Tinggi itu terpaksa ditutup, karena pemerintah Jepang hanya mengizinkan membuka sekolah/madrasah dari tingkat yang rendah saja. Dengan demikian berakhirlah riwayat Sekolah Islam Tinggi PGAI di Padang.

Pada masa-masa awal kemerdekaan dimensi perjuangan melawan kolonialisme Belanda begitu mewarnai PTAI. PTAI adalah jelas dipersepsi sebagai upaya memperkuat basis religio-intelektual generasi muda Muslim dalam menentang penjajahan. Pemerintah kolonial Belanda memang mendirikan beberapa perguruan tinggi di Indonesia, namun dengan daya tampung dan akses yang sangat terbatas serta dengan keberpihakan yang tak adil kepada kelompok elite. Akan tetapi perlu ditegaskan bahwa bagi sebagian besar masyarakat Muslim pada masa pra-kemerdekaan, memiliki PTAI bukanlah sebagai solusi

${ }^{7}$ Haidar Putra Daulay, Pendidikan Islam dalam Sistem Pendidikan Nasional di Indonesia (Jakarta: Kencana, 2006) h. 96.

${ }^{8}$ Mahmud Yunus, Sejarah Pendidikan Islam di Indonesia (Jakarta: Hidakarya, 1996), h. 278.

${ }^{9}$ Daulay, Pendidikan Islam, h. 97.

${ }^{10}$ Yunus, Sejarah Pendidikan Islam, h. 117-121. 
alternatif terhadap kebutuhan tersebut. PTAI adalah sebuah prinsip yang mengakomodasi sentimen keagamaan sekaligus semangat anti-kolonialisme mereka. Dari perspektif lain, tentu saja PTAI merupakan jawaban terhadap kebutuhan objektif generasi muda Muslim yang telah menyelesaikan pendidikan menengah, yang jumlahnya terus berkembang. ${ }^{11}$

Muhaimin mengatakan, bahwa aspirasi umat Islam pada umumnya dalam pengembangan pendidikan tinggi Islam pada mulanya didorong oleh beberapa tujuan. Pertama, untuk melaksanakan pengkajian dan pengembangan ilmu-ilmu agama Islam pada tingkat yang lebih tinggi secara lebih sistematis dan terarah. Kedua, untuk melaksanakan pengembangan dan peningkatan dakwah Islam. Ketiga, untuk mereproduksi dan kaderisasi ulama dan fungsionaris keagamaan, baik pada kalangan birokrasi negara maupun sektor swasta, serta lembaga-lembaga sosial, dakwah, pendidikan dan sebagainya. ${ }^{12}$ Berikut akan dipaparkan lembaga pendidikan tinggi Islam di Indonesia yang dimulai dari STI, UII, PTAIN, ADIA, IAIN, STAIN dan UIN.

\section{STI (Sekolah Tinggi Islam)}

Usaha untuk mendirikan PTI terus menggelora di kalangan umat Islam. Masyumi (Majelis Syura Muslimin Indonesia) merupakan gabungan dari organisasi Islam, ${ }^{13}$ memelopori untuk mendirikan PTI, pada bulan April 1945 diadakanlah rapat di Jakarta yang dihadiri oleh para tokoh organisasi Islam yang menjadi anggota Masyumi. Dalam rapat itu dihadiri sejumlah tokoh Islam, seperti (a) PBNU dihadiri KH. Abdul Wahab, KH. Bisri Syamsuri, KH. Wahid Hasyim, KH. Masykur dan Zainal Arifin, (b) PB Muhammadiyah dihadiri Ki bagus Hadikusumo, KH. Mas Mansur, KH. Hasyim, KH. Farid Ma'ruf, KH. Mu'thi, KH. M. Yunus Anis dan Kerto Sudarmo, (c) PB POI dihadiri KH. A. Halim dan H. Mansur, (d) PB Al-Islam dihadiri KH. Imam Ghazali, (e) Shumubu dihadiri A. Kahar Muzakar, KH. A. Moh. Adnan dan KH. Imam Zarkasi, (f) Cendekiawan Intelektual dihadiri Dr. Sukiman Wirjosandojo, Wondoamiseno, Abukusno Tjokrosujoyo, dan Muh. Roem. Sidang itu memutuskan untuk membentuk panitia perencana STI (Sekolah Tinggi Islam) yang dipimpin oleh Moh. Hatta dan sekretarisnya M. Natsir. Akhirnya atas bantuan Pemerintah Jepang, STI dibuka secara resmi pada tanggal 27 Rajab 1364 H bertepatan dengan tanggal 8 Juli 1945 di Jakarta. Peresmiannya diselenggarakan di gedung kantor Imigrasi Pusat Gondangdia di Jakarta. Kurikulum yang dipakai adalah mencontoh Fakultas Ushuluddin Universitas al-Azhar, Kairo ${ }^{14}$ h. 120 .

${ }^{11}$ Hasan Asari, Esai-Esai Sejarah Pendidikan, dan Kehidupan (Medan: el Misyka Circle, 2009),

${ }^{12}$ Muhaimin, Pemikiran dan Aktualisasi Pengembangan Pendidikan Islam (Jakarta: Rajawali Pres, 2012), h. 65-66.

${ }^{13}$ Firman Noor, "Islamic Party And Pluralism: The View and Attitude of Masyumi towards Pluralism in Politics (1945-1960)," dalam al-Jami'ah: Journal of Islamic Studies, Vol. 54, 2016, p. 275.

${ }^{14}$ Daulay, Pendidikan Islam dalam Sistem, h. 98-99. 


\section{UII (Universitas Islam Indonesia)}

UII sebuah perguruan tinggi Islam yang dibentuk dari STI. STI dalam sejarahnya tidak eksis dalam waktu yang panjang. Karena STI dibentuk pada masa kolonial Jepang yang masih berkuasa di Indonesia. Hanya dalam waktu 4 tahun STI eksis, kemudian dibentuklah UII. Jika dilihat akar historisnya, UII adalah hasil tranformasi STI. Transformasi STI menjadi UII sebagai bentuk pengembangan kelembagaan pendidikan tinggi Islam di Indonesia. Pada tanggal 22 Maret 1948 STI dirubah menjadi UII di Yogyakarta. UII pada tahun 1948 mempunyai 4 fakultas untuk menopang sebuah kelembagaan pendidikan tinggi. Salah satu fakultas tersebut nantinya menjadi cikal bakal kelahiran PTAIN. Adapun fakultas - fakultas tersebut yakni 1) fakultas Agama, 2) fakultas Hukum, 3) fakultas Ekonomi, dan 4) fakultas Pendidikan.

Ketika UII berdiri, ecara otomatis STI tidak ada lagi dalam bentuk perguruan tinggi, sebab namanya diganti menjadi UII. UII sebagai universitas masih tetap eksis sampai saat ini dan masih beroperasional. Namun UII bukanlah universitas Negeri seperti PTAIN, ADIA, IAIN, STAIN dan UIN. UII tidak dikelola oleh pemerintah, baik kelembagaan maupun manajemen. UII berstatus swasta bukan negeri. Kontribusi UII terhadap kemunculan perguruan tinggi Islam di Indonesia begitu besar dalam pengembangan pendidikan Islam. Menurut Mahmud Yunus, ${ }^{15}$ setelah fakultas Agama UII dijadikan PTAIN oleh Pemerintah, maka UII hanya memiliki fakultas Hukum, Ekonomi, dan Pendidikan (paedagogik). Kemudian, fakultas pendidikan terpaksa ditutup, karena kekurangan dosen-dosen, sehingga tinggal dua fakultas yakni fakultas Hukum dan Ekonomi. Fakultas Hukum ada dua buah: satu di Yogyakarta dan satu lagi di Solo (Surakarta).

\section{PTAIN (Perguruan Tinggi Agama Islam Negeri)}

Kelahiran PTAIN tidak dapat dipisahkan dari UII, kehadiran PTAIN dalam konstelasi pendidikan tinggi Islam di Indonesia merupakan bagian terpenting dalam mengembangkan pendidikan tinggi Islam. Karenanya, pada tanggal 12 Agustus 1950 menjadi sejarah awal kemunculan PTAIN, dimana fakultas agama yang berada di bawah pengelolaan UII dipisahkan dan diambil alih oleh pemerintah dalam rangka memperkuat kelembangaan pendidikan tinggi. Akhirnya, pada tanggal 26 September 1951 secara resmi dibuka perguruan tinggi baru dengan nama PTAIN (Perguruan Tinggi Agama Islam Negeri) yang langsung dibawah pengawasan Kementerian Agama Republik Indonesia. Historis PTAIN adalah kelanjutan dari fakultas agama UII. Artinya PTAIN tidak berdiri sendiri tanpa ada latar belakang yang kuat. Ini menandakan bahwa perguruan tinggi Islam di Indonesia mengalami dinamika seiring dalam perkembangan masyarakat dan kebutuhan umat Islam.

PTAIN didirikan di Yogyakarta pada tahun 1951 dengan peraturan pemerintah No. 34 tahun 1950 dan ditandatangani oleh Presiden Republik Indonesia tanggal 14 Agustus

\footnotetext{
${ }^{15}$ Yunus, Sejarah Pendidikan Islam, h. 289.
} 
1950. PTAIN berasal dari fakultas agama UII. Dengan demikian UII tidak mempunyai fakultas agama lagi. Hanya tinggal fakultas hukum, fakultas ekonomi dan fakultas paedagogik (pendidikan). ${ }^{16}$ Ramayulis menguatkan bahwa pada tanggal 26 September 1951 secara resmi dibuka perguruan tinggi baru dengan nama PTAIN (Perguruan Tinggi Agama Islam Negeri) di bawah pengawasan Kementerian Agama. ${ }^{17}$

\section{ADIA (Akademi Dinas IImu Agama)}

Disamping PTAIN sebagai milik bersama Departemen Agama dan Departemen Pendidikan, Pengajaran dan Kebudayaan didirikanlah Akademi Dinas Ilmu Agama (ADIA) di Jakarta dengan penetapan Menteri Agama No.1 Tahun 1957. Adapun tujuan ADIA tersebut sebagai sambungan dari usaha mendirikan Pendidikan Guru Agama Atas (PGAA) dan Sekolah Guru dan Hakim Agama (SGHA). Akademi Dinas Ilmu Agama bertujuan mendidik dan mempersiapkan pegawai negeri untuk mencapai ijazah semi akademi dan akademi untuk dijadikan ahli didik agama pada sekolah-sekolah lanjutan, baik umum maupun agama dan kejuruan. ${ }^{18}$

Pada tahun 1957, di Jakarta didirikan Akademi Dinas Ilmu Agama (ADIA). Akademi ini bertujuan sebagai sekolah latihan bagi para pejabat yang berdinas di Pemerintahan (Kementerian Agama) dan untuk pengajaran agama di sekolah. Lama studi di ADIA 5 tahun yang terdiri dari dua tingkat yaitu; tingkat semi akademi 3 tahun dan tingkat akademi 2 tahun. Tiap-tiap tingkat memiliki dua jurusan: jurusan pendidikan Agama dan Jurusan sastra. ${ }^{19}$ ADIA di tujukan untuk meningkatkan kualitas pegawai negeri dalam bidang Keagamaan. ${ }^{20}$ ADIA terbuka hanya bagi pegawai-pegawai negeri. Setiap tahun atas usul kepala Jawatan Pendidikan Agama ditunjuk oleh Menteri Agama sejumlah pegawai negeri, supaya dengan tugas belajar mengikuti pendidikan pada Akademi itu. ${ }^{21}$

\section{IAIN (Institut Agama Islam Negeri)}

Kehadiran Institut Agama Islam Negeri dalam perkembangan PTKIN di Indonesia memiliki akar sejarah yang sangat kuat. Dimana lembaga ini tidak dilahirkan begitu saja tanpa ada latar belakang yang membentuknya. IAIN merupakan transformasi dari perguruan

${ }^{16} \mathrm{Ibid}$, h. 396.

${ }^{17}$ Ramayulis, Sejarah Pendidikan Islam, h. 369.

${ }^{18}$ Syamsuddin Abdullah, Agama dan Masyarakat Pendekatan Sosiologi Agama (Jakarta: Logos Wacana Ilmu, 1997), h. 2.

${ }^{19}$ Ramayulis, Sejarah Pendidikan Islam, h. 369.

${ }^{20}$ Samsul Nizar, et al., Sejarah Sosial dan Dinamika Intelektual Pendidikan Islam di Indonesia (Jakarta: Kencana, 2013), h. 336.

${ }^{21}$ Mahmud, Sejarah Pendidikan Islam, h. 404. 
tinggi yang telah terbentuk sebelumnya di Indonesia. Kehadirannya telah memberikan dampak positif bagi pengembangan pendidikan Islam di Indonesia.

Pada bulan Mei tahun1960 merupakan langkah penting yang memberikan kesan yang tidak terlupakan, yaitu Kementerian Agama mengabungkan PTAIN dan ADIA menjadi Institut Agama Islam Negeri (IAIN) atau Al-Jami'atul al-Islamiyah al-Hukumiyah. IAIN pertama dibuka secara resmi di Yogyakarta pada tanggal 24 Agustus 1960 oleh Menteri Agama RI yaitu K.H. Wahid Wahab, pada tahap awal IAIN terdiri dari beberapa fakultas; fakultas Ushuluddin, Syari'ah, Tarbiyah dan Fakultas Adab. Masing-masing fakultas memiliki beberapa jurusan. ${ }^{22}$

Menurut Azyumardi Azra, dilihat dari segi usia, IAIN sebetulnya termasuk perguruan tinggi relatif cukup mapan di tanah air. Kehadiran IAIN tidak telepas dari cita umat Islam Indonesia memajukan ajaran Islam di Indonesia. IAIN diharapkan mampu memberikan respons dan jawaban Islam terhadap tantangan zaman. Ia hendaklah dapat memberikan warna dan pengaruh keislaman kepada masyarakat Islam secara keseluruhan. Semua ini dapat disebut sebagai ekspektasi sosial IAIN. Pada saat yang sama IAIN juga diharapkan mampu menjadikan dirinya sebagai pusat studi dan pengembangan Islam. Inilah ekspektasi akademis kepada IAIN. Dengan demikian, IAIN memikul dua harapan yaitu sosial exspectation dan academic expectations. ${ }^{23}$

\section{STAIN (Sekolah Tinggi Agama Islam Negeri)}

Sekolah Tinggi Agama Islam Negeri (STAIN) merupakan lembaga pendidikan tinggi Islam Indonesia. STAIN adalah lembaga baru setelah IAIN. STAIN juga tidak terlepas dari akar sejarah kemunculannya. Artinya STAIN sebagai institusi pendidikan Islam tidaklah lembaga yang dikonstruk tanpa latar belakang yang jelas, namun terbentuk seiring dengan perkembangan IAIN. Kehadiran STAIN juga tidak memiliki pengaruh pada IAIN, dalam pengertian bahwa setelah STAIN terbentuk IAIN dihilangkan. Justeru kemunculan STAIN untuk memperkuat kelembagaan IAIN dalam mengembangkan pendidikan Islam untuk masyarakat.

Pemerintah dalam hal ini Departemen Agama nampaknya berusaha terus meningkatkan mutu IAIN yang ada di Indonesia. Berdasarkan Keputusan Presiden No. 11 tahun 1997 dan Keputusan Menteri Agama RI Nomor 285 tahun 1997, maka dari 38 buah seluruh fakultas cabang yang masih ada di daerah statusnya menjadi Sekolah Tinggi Agama Islam Negeri (STAIN). Dengan adanya keputusan ini, maka seluruh STAIN bebas mengembangkan diri karena tidak lagi dikendalikan oleh IAIN, bahkan sudah ada beberapa STAIN berubah statusnya

\footnotetext{
${ }^{22}$ Nizar, et al., Sejarah Sosial dan Dinamika, h. 336.

${ }^{23}$ Azyumardi Azra, Pendidikan Islam: Tradisi dan Modernisasi di Tengah Tantangan Milinium III, cet. 2 (Jakarta: Kencana, 2014), h. 194-198.
} 
menjadi IAIN seperti STAIN Serang, dan bahkan ada yang menjadi UIN, seperti STAIN Malang berubah menjadi UIN Malang. ${ }^{24}$ Hal senada dikatakan Moh. Roqib, pada 1997, fakultasfakultas di daerah tersebut kemudian dimandirikan menjadi Sekolah Tinggi Agama Islam Negeri (STAIN) yang kadang disebut dengan IAIN mini. Perubahan ini merupakan gejala positif bagi STAIN meskipun masih sering dipertanyakan statusnya dalam sistem pendidikan di Indonesia. ${ }^{25}$

\section{UIN (Universitas Islam Negeri)}

PTKIN di Indonesia secara gradual terus mengalami perkembangan ke arah universitas. Ini menunjukkan bahwa perguruan tinggi yang dulu dibentuk dan dikonstruksi oleh pendahulu, kini telah mencapai pada level universitas. Awalnya STI, UII, PTAIN, ADIA, IAIN, STAIN dan kemudian menjadi UIN. Tentunya, ini merupakan suatu proses sejarah dalam dunia pendidikan Islam di Indonesia. Cita-cita pendahulu dalam meneguhkan perguruan tinggi Islam mendapat dukungan yang besar pada generasi belakangan, faktanya bahwa dari waktu ke waktu PTKIN di Indonesia terus mengalami kemajuan.

Universitas Islam Negeri (UIN) merupakan lembaga perguruan tinggi Islam yang berbentuk Universitas. Sebelumnya dalam konstelasi PTKIN di Indonesia memang ada Universitas, akan tetapi dalam bentuk swasta yakni UII (Universitas Islam Indonesia). Perguruan tinggi ini sudah lama terbentuk di Indonesia. Jika kemudian lahir Universitas Islam Negeri (UIN), sebetulnya bukanlah sesuatu yang langka dan baru. Justeru UII menjadi inspirasi atas kelahiran UIN, meskipun salah satu faktor, disamping faktor-faktor lain yang melatarbelakangi kelahiran UIN. Setidaknya, Universitas Islam sudah pernah digagas sebelumnya. Hal senada juga dikatakan Badri Yatim, ${ }^{26}$ Universitas Islam Indonesia (UII) adalah perguruan tinggi pertama yang memiliki fakultas-fakultas non agama. Dengan demikian, ia dapat memberi contoh tentang perkembangan universitas-universitas Islam di Indonesia. PTKIN yang pertama membuat persiapan menjadi UIN ialah IAIN Syarif Hidayatullah, sehingga pada tahun 2002 IAIN Syarif Hidayatullah menjadi UIN Syarif Hidayatullah.

\section{Perubahan IAIN dan STAIN Menjadi UIN}

Perkembangan dan dinamika keilmuan manusia tidak terlepas dari perkembangan situasi perkembangan zaman yang ada. Kenyataan masyarakat yang selalu berubah tidak dapat dipungkiri lagi seiring pemikiran manusia yang dinamis. Semangat keilmuan dalam

\footnotetext{
${ }^{24}$ Ramayulis, Sejarah Pendidikan Islam, h. 371.

${ }^{25}$ Moh. Roqib, Ilmu Pendidikan Islam: Pengembangan Pendidikan Integratifdi Sekolah, Keluarga, dan Masyarakat (Yogyakarta: LKiS, 2009), h. 169.

${ }^{26}$ Badri Yatim, Sejarah Peradaban Islam (Jakarta: RajaGrafindo Persada, 2003), h. 312.
} 
pendidikan Agama harus senantiasa merespons perkembangan global sehingga pendidikan agama bukan semata aspek moralitas, sikap toleransi dan kebersamaan, tujuan jangka panjang rahmatan li al-âlamîn, namun semangat keilmuan yang akan dibangun di masa mendatang dengan bertitik pangkal pada spirit agama dan etos kerja keilmuan yang telah diajarkan dalam setiap agama. ${ }^{27}$ Tantangan modernisasi dan globalisasi yang cenderung membawa manusia menuju eksistensi, humanistik, hedonistik, eksklusivisme, dan yang lebih buruk adalah dekadensi moral yang melanda hampir semua aspek kehidupan manusia. ${ }^{28}$

\section{Argumentasi Konversi IAIN/STAIN Menjadi UIN}

Ada 7 argumentasi terjadinya konversi IAIN dan STAIN menjadi UIN dan argumentasi ini lahir untuk mengemukakan aspek-aspek yang melatarbelakangi konversi PTKIN di Indonesia dan melihat perjalanan PTKIN dalam pentas sejarah bangsa Indonesia. Adapun Argumentasi perubahan kelembagaan PTKIN tersebut yaitu:

\section{Argumentasi Politik}

Transformasi kelembagaan tidak terlepas dari persoalan politik. ${ }^{29}$ Kebijakan politik dalam dunia pendidikan akan memberi pengaruh pada PTKIN. Kebijakan tersebut akan merubah lembaga pendidikan tinggi Islam, baik secara kelembagaan maupun dalam manajemen pengelolaannya terkait dengan kebijakan politik pemerintah. Seperti yang diungkapkan Haidar Putra Daulay ${ }^{30}$ suatu hal yang sangat mengembirakan umat Islam saat ini adalah kebijakan pemerintah tentang perguruan tinggi. Pada prinsipnya pemerintah memberi peluang yang sama bagi perguruan tinggi negeri dan swasta untuk berkembang. Berlomba berpacu dalam konsep fastabiq al-khairat (berlomba-lomba untuk kebaikan).

\section{Argumentasi Sosial-Ideologis}

Masyarakat Indonesia adalah mayoritas beragama Islam, tentu kebutuhan terhadap lembaga pendidikan pendidikan tinggi Islam sangat diharapkan kehadirannya. Meskipun terdapat lembaga pendidikan Islam lainnya, seperti pesantern dan madrasah. Masyarakat Indonesia menginginkan adanya sebuah perguruan tinggi Islam yang representatif sebagai

${ }^{27}$ Musthofa Rembangy, Pendidikan Transformatif: Pergulatan Kritis Merumuskan Pendidikan di tengah Pusaran Arus Globalisasi (Yogyakarta: Teras, 2008), h. 224.

${ }^{28}$ Syahrizal, "Pemikiran Pendidikan Islam Ibn Sahnun: Analisis Kritis Kurikulum Pengajaran di Institusi Pendidikan Dasar Islam," dalam MIQOT: Jurnal Ilmu-ilmu Keislaman, Vol. XXXVI, p. 150.

${ }^{29}$ Moch Tolchah, "The Political Dimension of Indonesian Islamic Education In The Post-1998 Reform Period," dalam Journal of Indonesian Islam, Vol. 08, 2014.

${ }^{30}$ Haidar Putra Daulay, Kapita Selekta Pendidikan Islam di Indonesia (Medan: Perdana Publishing, 2012), h. 169 
tempat belajar agama Islam, sekaligus belajar ilmu pengetahuan umum. Sebab, pengetahuan agama itu penting, akan tetapi ilmu pengetahuan umum juga penting bagi generasi masa depan bangsa. Transformasi ini, sesungguhnya untuk menjawab kebutuhan masyarakat agar di Indonesia memiliki lembaga pendidikan Islam yang akomodatif, produktif dan representatif. Oleh karena itu, kelahiran UIN merupakan solusi akademis dan menjawab keinginan masyarakat. Secara sosiokultural, masyarakat menaruh harapan yang tinggi atas kelahiran UIN dan menjadi tempat pewarisan budaya dan ilmu pengetahuan.

\section{Argumentasi Kelembagaan}

Dilihat secara kelembagaan, baik IAIN, STAIN dan UIN didirikan oleh pemerintah agar lembaga tersebut dapat berperan dalam konstalasi keilmuan sekaligus untuk mencerdaskan bangsa. Di samping itu, konversi atau transformasi kelembagaan STAIN dan IAIN menjadi UIN atau STAIN menjadi IAIN, tidak lain adalah untuk memberikan peluang kepada perguruan tinggi tersebut lebih leluasa dalam mengembangkan ilmu pengetahuan dan mempermudah untuk menempa peserta didik untuk menjadi lulusan yang profesional dan mampu berkompetisi di era globalisasi yang kian kompetitif, baik secara kelembagaan maupun lulusan atau outputnya. Menurut Azyumardi Azra, ${ }^{31}$ IAIN dimaksudkan untuk memperbaiki dan memajukan pendidikan tenaga ahli agama Islam guna keperluan pemerintah dan masyarakat.

\section{Argumentasi Dunia Kerja}

PTKIN dalam pengembangan keilmuan harus berbasis kepada peningkatan kualitas dan keterampilan mahasiswa, sehingga lulusan dari PTKIN dapat terserap dalam semua sektor publik. Jika tidak diarahkan pengembangannya kepada peningkatan kualitas, maka PTKIN akan kehilangan pengaruhnya di dalam masyarakat. Sebab, selama ini lulusan PTKIN lebih banyak bekerja di instansi Kementerian Agama, atau pada instansi yang membutuhkan lulusan PTKIN untuk ditempatkan dalam bidang keagamaan saja. Akhirnya, lulusan PTKIN terbatas serapan dalam dunia kerja. Jadi Konversi IAIN dan STAIN menjadi UIN adalah suatu keniscayaan dalam menjawab tuntutan dunia kerja.

\section{Argumentasi Keilmuan}

Keilmuan secara akademis merupakan substansi dari sebuah perguruan tinggi. Tentunya, transformasi membuka ruang bagi penguatan keilmuan. Konversi yang dilakukan di wilayah PTKIN akan memberikan ruang yang besar bagi pengembangan keilmuan, misalnya IAIN dan STAIN berubah menjadi UIN. UIN sebuah perguruan tinggi yang berbentuk universitas

\footnotetext{
${ }^{31}$ Azyumardi Azra, Pendidikan Islam, h. 195.
} 
diberikan ruang dan kesempatan untuk membuka program studi umum, di samping program studi keislaman terus diperkuat pada kelembagaan tersebut setelah dilakukan transformasi. Artinya, kesempatan untuk memperkuat dan mengembangkan keilmuan terbuka lebar. Tidak hanya dalam ranah ilmu keislaman saja, akan tetapi ilmu umum juga menjadi fokus UIN.

\section{Argumentasi Pembangunan Bangsa Dan Negara}

Pembangunan bangsa dan negara merupakan hal terpenting dan utama, sebab PTKIN adalah lembaga pendidikan Islam yang dibentuk dan diprakarsai oleh negara, dalam hal ini tentunya Pemerintah Republik Indonesia. Oleh karena itu, kehadiran PTKIN di masyarakat adalah untuk membentuk manusia Indonesia yang memiliki pegetahuan agama yang baik, dan menguasa keilmuan lainnya yang dapat membangun bangsa dan negara. Ini merupakan argumentasi akademis dan logis, manakala PTKIN ditransformasi kepada bentuknya yang lebih ideal, maka perguruan tinggi tersebut diberikan wewenang yang lebih luas untuk berpartisipasi dalam pembangunan bangsa dan negara dalam berbagai sektor. UIN, misalnya sebuah contoh kongkrit dari transformasi, dimana UIN dengan kapasitas dan kewenangan yang diberikan secara kelembagaan dapat lebih leluasa dalam merumuskan kebijakan lembaga, pengembangan keilmuan dan pencerdasan kehidupan bangsa. Sebab, pendidikan Islam berfungsi dalam pembangunan bangsa dan negara.

\section{Argumentasi Kompetisi Global}

Dengan semakin terbukanya Indonesia dalam proses globalisasi, maka tidak terhindar adanya persaingan yang terbuka. Untuk memasuki persaingan global ini dituntut kemampuan teknologi (dalam rangka kualitas produk), kemampuan manajemen (dalam rangka ketepatan delivery), efesiensi yang tinggi (dalam persaingan harga). ${ }^{32}$ Konversi kelembagaan PTKIN, sebagai respons atas perkembangan dunia saat ini, suka tidak suka (like and dislike) perubahan dalam berbagai bidang akan terus terjadi. Oleh karena itu, transformasi ini menjadi titik awal kebangkitan perguruan Tinggi Islam di Indonesia dalam mengepakkan sayapnya dalam penguatan kualitas lulusan. Sebab, persepsi sekarang ini, bahwa semua lulusan PTKIN, khususnya STAIN dan IAIN dianggap memiliki keahlian (expert) dalam bidang ilmu keislaman saja, dan memiliki keterbatasan dalam bidang di luar ilmu keislaman, sehingga alumni perguruan tinggi Islam dihadapakan pada situasi yang sulit untuk mengembangkan dirinya. Menurut Muh. Idris ${ }^{33}$ bahwa ilmuwan menyebut fenomena ini sebagai globalisasi. Globalisasi dalam konteks ilmu sosial menjadi wacana yang menarik.

\footnotetext{
${ }^{32}$ Muhammad Tholhah Hasan, Islam dan Masalah Sumber Daya Manusia (Jakarta: Lantabora Pers, 2003) h. 227-228.

${ }^{33}$ Muh. Idris, "Konsep Pendidikan Humanis dalam Pengembangan Pendidikan Islam," dalam MIQOT: Jurnal Ilmu-ilmu Keislaman, Vol. XXXVIII. p. 422.
} 


\section{Argumentasi Prinsip Keterbukaan}

Peralihan bentuk perguruan tinggi dari satu bentuk ke bentuk lain sudah seyogyanya menganut sistem terbuka dan menerapkan prinsip meiritologi dan non-diskriminatif. Pada kondisi tertentu yang memang dipahami terbuka bersama, suatu kebijakan affirmatif dan reformatif terkadang diperlukan dan memang lebih bijaksana dan adil. Keadilan ini tentu dengan mengingat prinsip treating unequally. Jika sebaliknya, dalam artian treating equals un equally dan treating unequally merupakan suatu yang berseberangan dengan prinsip equality dan justice. ${ }^{34}$

Manajemen perguruan tinggi harus transparan dan akuntabel, sehingga semua pihak dapat mengakses berbagai informasi yang ada dan sedang dikembangkan oleh perguruan tinggi. Hal ini perlu diperhatikan oleh pengelola atau pihak manajemen perguruan tinggi. Transparansi dan akuntabel merupakan bentuk lembaga yang bagus dan dipandang sehat dari sisi manajemen dan kepimpinan. Sebab, kampus mengusung iklim akademis, tentu semua civitas akademika harus berpikir ke arah yang positif dan memiliki kejujuran dan keterbukaan. Begitu juga halnya dengan kepemimpin pada perguruan tinggi, dimana seorang pemimpin harus membuka ruang yang demokratis dan tanpa diskriminasi terhadap semua insan kampus.

\section{Karakteristik Transformasi PTKIN di Indonesia}

Transformasi PTKIN di Indonesia terus berlanjut sejak didirikan STI pada bulan Juli tahun 1945 sampai dengan alih status IAIN dan STAIN menjadi UIN pada tahun 2002. Meskipun STI dan UII bukan perguruan tinggi negeri, akan tetapi cikal bakal PTKIN tidak bisa dilepas dari sejarahnya. Dari UII, kemudian terbentuk PTKIN di Indonesia. Transformasi PTKIN memiliki karakteristik tersendiri dan mempunyai keunikannya, baik dilihat dari aspek kelembagaan maupun aspek keilmuan. Di sisi lain, faktor politik dan aspirasi umat Islam Indonesia menjadi bagian yang utuh dari transformasi PTKIN.

Usia PTKIN di Indonesia dapat dilihat dari dua sisi. Pertama, jika sejarah PTKIN dilihat dari STI pada tahun 1945, maka usia PTKIN sampai dengan tahun 2016 di Indonesia sudah 71 tahun. Kedua, jika sejarah PTKIN diambil dari sejarah berdirinya PTAIN pada tahun 1951, maka usia PTKIN sampai dengan tahun 2016 sudah berusia 65 tahun. Baik dilihat dari sejarahnya pada tahun 1945 dan 1951, namun setidaknya usia PTKIN sudah relatif lama berkiprah dalam sejarah Indonesia. Jumlah PTKIN terus berkembang di seluruh Provinsi dan kota di Indonesia. Terhitung bulan Desember 2015, IAIN sudah berjumlah 25 buah lembaga, STAIN berjumlah 19 buah lembaga dan UIN berjumlah 11 lembaga.

Tranformasi PTKIN berlangsung dalam kurun waktu 71 tahun sejak pembentukan

\footnotetext{
${ }^{34}$ Nur A. Fadhil Lubis, Rekonstruksi Pendidikan Tinggi Islam: Memberi Makna Kelahiran UINSU (Bandung: Citapustaka Media, 2014) h. 62.
} 
STI. IAIN dari tahun 1960 - 1973 berjumlah 14 buah, pada tahun 2015 menjadi 25 buah lembaga. Sedangkan STAIN yang didirikan oleh pemerintah pada tahun 1973 berjumlah 33 buah, kemudian pada tahun 2015 jumlah STAIN 19 buah lembaga. Sedangkan UIN dari tahun 2002 dibentuk pertama kali IAIN Syarif Hidayatullah menjadi UIN Syarif Hidayatullah, dan pada tahun 2015 jumlah UIN sudah mencapai 11 buah lembaga.

Secara politik kemunculan STI berada dalam situasi politik yang masih belum stabil di Indonesia pada tahun 1945. Dilihat dari aspek kelembagaan karakteristik STI berbentuk 'Sekolah Tinggi'. Sedangkan karakteristik keilmuan STI masih dalam lingkup studi Islam. Hal ini dapat dipahami kehadiran STI sebagai lembaga lanjutan alumni pasantren dan madrasah untuk menempuh pendidikan tinggi. STI dibentuk pada awalnya bukanlah berbentuk universitas yang terintegrasi ilmu.

Kemudian pada tahun 1948 STI ditranformasikan menjadi UII yang secara kelembagaan berbentuk 'universitas'. Artinya, umat Islam pada saat itu sudah berfikir untuk mendirikan perguruan tinggi dalam bentuk universitas Islam yang di dalamnya terintegrasi ilmu antara ilmu agama dan ilmu umum. Karakteristik transformasi STI menjadi UII lebih kepada keinginan untuk memiliki sebuah perguruan tinggi yang representatif dan terpercaya serta menjadi tempat untuk mencerdaskan masyarakat Indonesia dalam berbagai keilmuan, sehingga generasi bangsa tidak hanya pintar dalam bidang agama Islam saja, akan tetapi juga menguasai ilmu pengetahuan lainnya. Sebab, STI tidak mampu untuk mencerdaskan generasi bangsa dalam ilmu pengetahuan umum. Jadi, transformasi tersebut untuk kepentingan keilmuan dan mencerdaskan semua masyarakat Indonesia. Bukti bahwa UII terintegrasi ilmu di dalamnya dengan dilihat dari fakultas-fakultas yang dibuka yaitu Fakultas Agama Islam, Fakultas Hukum, Fakultas Ekonomi dan Fakultas Pendidikan. Ide kemunculan UII di kalangan umat Islam pada saat itu, sepertinya mencontoh bentuk kelembagaan Universitas al-Azhar, Kairo, khususnya fakultas Ushuluddin, sehingga karakteristik keilmuan STI sama dengan fakultas ini.

Jika dilihat karakterisik transformasi STI menjadi UII lebih kepada persoalan integrasi ilmu dan pengaruh dari pembaharuan di Mesir. Akhirnya UII menjadi sebuah perguruan tinggi yang berbentuk universitas Islam yang pertama di Indonesia. Kemudian pada tahun 1951 pemerintah mengambil Fakultas Agama Islam di UII menjadi PTAIN. Fakultas Agama Islam UII dinegerikan oleh pemerintah dan menjadi kewenangan pemerintah dalam pelaksanaan dan pengelolaan PTAIN tersebut. Uniknya, pemerintah hanya menegerikan satu fakultas saja dan tidak menegerikan UII menjadi UIN seperti yang didirikan pada tahun 2002 di Jakarta.

PTAIN bukanlah berbentuk universitas karena di dalamnya tidak terintegrasi ilmu seperti pada UII. Secara kelembagaan PTAIN berbentuk 'Sekolah Tinggi' sama seperti STI dengan beberapa jurusan di dalamnya. Transformasi fakultas Agama Islam UII menjadi PTAIN tidak didasari pada visi integrasi ilmu. Pada sisi lain, pemerintah mendirikan ADIA dalam bentuk akademi. ADIA tidak terintegrasi ilmu di dalamnya, justeru ADIA lebih eksklusif 
dalam makna bahwa ADIA khusus dibentuk untuk para pegawai negeri saja. ADIA tidak diperuntukkan untuk masyarakat Indonesia secara umum.

Kemudian PTAIN dan ADIA ditansformasikan kembali oleh pemerintah menjadi IAIN. Semangat integrasi ilmu yang pada awalnya ada pada UII, kemudian menjadi buram ketika transformasi yang dilakukan oleh pemerintah pada saat didirikan IAIN pada tahun 1960 bukan berbentuk 'Universitas', seperti UII. Akan tetapi berbentuk 'Institut'. Fakultasfakultas IAIN yang berada di provinsi dan kota di Indonesia diresmikan menjadi STAIN. STAIN, karakteristiknya juga tidak mengintegrasikan ilmu di dalamnya. STAIN lebih khusus pada pengelolaan satu rumpun keilmuan Islam. Secara kelembagaan setingkat di bawah IAIN atau dapat disebut IAIN mini. Kehadiran IAIN dan STAIN dalam peta PTKIN tidak beroperasi dalam integrasi ilmu, justeru IAIN dan STAIN ikut serta merawat dan meperkuat dikotomi ilmu antara pendidikan agama dan pendidikan umum. IAIN dan STAIN hanya diberikan wewenang untuk melaksanakan dan bergerak dalam keilmuan agama saja. IAIN dan STAIN tidak memiliki kewenangan melebihi ketentuan yang diberikan pemerintah. Dalam bahasa Azra ${ }^{35}$, IAIN dan STAIN memang pernah main "kucing-kucingan" dengan Kementerian Pendidikan Nasional (Kemendiknas) ketika membuka program 'Tadris' di fakultas Tarbiyah, yang sebenarnya merupakan program-program studi umum yang menjadi mandat istimewa Kemendiknas belaka.

Keinginan mendirikan sebuah universitas Islam bergulir kembali dalam konstelasi pemikiran para akademisi dan umat Islam menjelang tahun 2002. Akhirnya, keinginan untuk mendirikan perguruan tinggi Islam dalam bentuk universitas muncul kembali. Akhirnya, pada tahun 2002, IAIN Syarif Hidayatullah diubah menjadi UIN, dan disusul STAIN Malang menjadi UIN Malang.

Karakteristik yang paling kentara adalah di mana posisi ilmu yang pada awalnya dikonstruksi secara monolitik dan dikotomi pada STI. Selanjutnya, posisi ilmu dipandang tidak dikotomi dengan adanya UII. Ketika UII dibentuk, posisi ilmu dipandang utuh dan tidak ada disparitas. Akhirnya ilmu dikotomi kembali dengan didirikan PTAIN, ADIA, IAIN dan STAIN. Durasi waktu yang panjang dari tahun 1951 sampai tahun 2002, posisi ilmu dipandang tidak terintegrasi, kemudian ilmu dipandang terintegrasi pada tahun 2002, sebagai faktanya didirikan UIN. Jadi, posisi keilmuan dan karaktristik kelembagaan tidak berjalan linier dalam sejarah transformasi PTKIN, akan tetapi berjalan fluktuatif dan secara gradual kembali pada posisi awal yang memandang ilmu lebih universal dan integratif. Dengan adanya UIN dengan konsep integrasi ilmu, maka akan menghasilkan perkembangan yang cukup mengembirakan, dalam istilah Azra disebut beyond imagination, suatu kondisi yang tidak pernah dibayangkan sebelumnya, di mana santri-santri di UIN dapat menjadi ahli ekonomi, ahli kedokteran, ahli teknologi, ahli politik, dan sebagainya, di samping ahli di bidang agama Islam.

${ }^{35}$ Azyumardi Azra, Pendidikan Islam, h. 294. 


\section{UIN Format Ideal PTKIN}

Perkembangan ilmu pengetahuan dan teknologi di era globalisasi berdampak terhadap semua dimensi kehidupan sosial. Kondisi ini terus bergulir dalam dinamika kehidupan masyarakat, bahkan PTKIN juga mengalami dampak dari perkembangan tersebut. Oleh karena itu, PTKIN terus berupaya memperbaharui kelembagaan dan kurikulumnya, sehingga PTKIN dapat lebih bertahan dan memiliki ketangguhan dalam menghadapi perubahan yang terjadi di era globalisasi. Seperti yang dikatakan Muzayyin Arifin, ${ }^{36}$ akhir-akhir ini, akibat timbulnya perubahan sosial di berbagai sektor kehidupan umat manusia, beserta nilainilainya ikut mengalami pergeseran yang belum mapan. Pendidikan Islam seperti dikehendaki umat Islam, harus mengubah strategi dan taktik operasional. Strategi dan taktik itu tak pelak lagi menuntut perombakan model-model sampai dengan institusi-institusinya sehingga lebih efektif dan efesien, dalam artian paedagogis, sosiologis dan kultural.

UIN adalah salah satu cabang PTKIN di Indonesia yang idealnya merespon globalisasi. Ini telah menerapkan sains terpadu dalam kurikulumnya, dengan meminjam metafora Amin Abdullah, "jaringan sains laba-laba”, di mana di antara berbagai disiplin ilmu saling terkait satu sama lain. ${ }^{37}$ Intinya, UIN merupakan harapan bagi semua orang, terutama bagi umat Islam dan umumnya untuk masyarakat Indonesia. Ini tidak hanya berfokus pada studi Islam, tapi juga pengetahuan lainnya. Tujuannya adalah untuk mengintegrasikan ilmu yang sebelumnya dilihat dalam paradigma dikotomis. Oleh karena itu lulusan PTKIN tidak mampu merespon kebutuhan masyarakat. Jika lulusan PTKIN memiliki akses terbatas, maka barang tersebut tidak dapat dipasarkan, berarti mereka tidak dapat mengikuti setiap sektor bisnis. Oleh karena itu, UIN merupakan solusi untuk merespon dinamika ilmiah dan tuntutan kerja.

Bilgrami dan Ashraf memberikan beberapa batasan sebagai prasyarat bagi perguruan tinggi untuk disebut sebagai universitas Islam. Pertama, adanya konsep pendidikan yang diperluas berdasarkan integrasi yang bersifat umum. Kedua, kebutuhan konseptualisasi dan redefinisi pendidikan. Ketiga, kebutuhan dedikasi, pengabdian, penguasaan ilmu pengetahuan, pemikiran kritis dan keluasan visi staf sebagai motor atau sumber daya manusia. Keempat, seleksi dengan standar spesifik yang diterapkan pada siswa. Kelima, pembentukan administrasi dan tradisi organisasi yang rapi. Keenam, pemenuhan konsep islamisasi pengetahuan dalam konteks forum akademik yang lebih luas dan bebas. Ketujuh, perlunya upaya pengembangan kurikulum untuk inti dan ilmu pelengkap. ${ }^{38}$

PTKIN di Indonesia yang paling ideal dalam merespon globalisasi adalah UIN. UIN

${ }^{36}$ Muzayyin Arifin, Kapita Selekta Pendidikan Islam (Jakarta: Bumi Aksara, 2007), h. 4-5.

${ }^{37}$ Amin Abdullah, "Religion, Science And Culture: An Integrated, Interconnected Paradigm of Science," dalam al-Jamiah: Journal of Islamic Studies, Vol. 52, 2014, p. 182.

${ }^{38}$ Lias Hasibuan, "Pengembangan Sistem Perkuliahan Kompetensi di Perguruan Tinggi Agama Islam," dalam MIQOT: Jurnal Ilmu-ilmu Keislaman, Vol. XXXII, p. 259. 
dalam kurikulumnya sudah memberlakukan integrasi ilmu sebagai basis kurikulumnya. Tentunya, UIN menjadi harapan semua orang, khususnya umat Islam dan bangsa Indonesia pada umumnya. UIN tidak hanya fokus pada ilmu keislamanan saja, akan tetapi ilmu pengetahuan lainnya di luar ilmu keislamanan. Sebab, tujuan UIN dilahirkan untuk mengintegrasikan ilmu yang selama ini ilmu dipandang dalam paradigma dikotomi, sehingga lulusan dari PTKIN tidak mampu menjawab kebutuhan masyarakat. Jika lulusan PTKIN terbatas geraknya, maka lulusan tersebut tidak marketable, artinya tidak dapat berkiprah dalam semua sektor dunia usaha. Karena itu, UIN adalah solusi untuk menyahuti dinamika keilmuan dan tuntutan dunia kerja. UIN merupakan model PTKIN yang ideal di era globalisasi, di mana UIN mengembangkan multi dispilin ilmu dalam konsep integrasi ilmu.

Semua lembaga ini diharapkan berfungsi sebagai model, atau paling tidak akan berkembang menjadi model, lembaga pendidikan tinggi yang benar-benar Islami. Lembagalembaga pendidikan ini diharapakan akan, melahirkan manusia yang berbeda dari produk universitas ala Barat. Sejauh ini pro dan kontra masih menghiasai diskusi tentang lembagalembaga tersebut. Kenyataan yang dapat dinilai sebagai tanda adanya kreativitas dari mereka yang memikirkannya. Umat Islam Indonesia masih harus menunggu pematangan lembaga ini, untuk kemudian melihat produk yang dihasilkannya. Sebagai Muslim, tentu saja mereka menanti dengan penuh harap. ${ }^{39}$ Pendidikan Islam bukan semata-mata pendidikan yang mengajarkan doktrin hukum agama, namun ruang lingkupnya jauh lebih luas dari itu. ${ }^{40}$

UIN dapat menjadi pusat pengembangan ilmu pengetahuan di Indonesia bahkan di manca negara. UIN setidaknya menjadi contoh dan model pendidikan tinggi Islam yang representatif dalam rangka membangun peradaban dan paradigma integratif. Paradigma partial tidak begitu efektif dalam menjawab dan memecahkan persoalan bangsa dan negara, begitu juga dalam hal keilmuan. Paradigam partial justeru mempersempit jalan untuk memahami persoalan, baik dalam bidang keagamaan maupun dalam kehidupan berbangsa dan mengubah wajah dunia dan mengantarnya ke era modern adalah ilmu pengetahuan dan teknologi.

PTKIN yang adaptif-responsif adalah UIN dalam menghadapi era globalisasi dan menjawab multi kebutuhan masyarakat, tidak bermakna bahwa PTKIN lainnya, seperti IAIN dan STAIN tidak survive. Bahkan IAIN dan STAIN terus berkembang dan diminati oleh masyarakat. Meskipun, upaya IAIN dan STAIN terus mempersiapkan dirinya menjadi UIN. Ini artinya bahwa menjadi UIN adalah pilihan yang tepat. Bukan tidak mungkin pada suatu hari semua IAIN dan STAIN menjadi UIN. Tentu, hanya persoalan waktu dan kesiapan IAIN dan STAIN menjadi UIN.

\footnotetext{
${ }^{39}$ Hasan Asari, Menyingkap Zaman Keemasan Islam (Bandung: Cita Pustaka Media, 2007), h. 241-242.

${ }^{40}$ Hasbullah Hadi, et al., "Kebijakan Pendidikan Nasional terhadap Pendidikan Islam dan Pendidikan Sekuler," dalam MIQOT: Jurnal Ilmu-ilmu Keislaman, Vol. XL. h. 392.
} 


\section{Penutup}

Umat Islam Indonesia mendirikan perguruan tinggi Islam pertama, yakni STI (Sekolah Tinggi Islam) di Jakarta pada tahun 1945. Kemudian, STI ditransformasi menjadi UII (Universitas Islam Indonesia), didirikan pada tahun 1948 di Yogyakarta. Selanjutnya, pemerintah mendirikan PTAIN (Perguruan Tinggi Agama Islam Negeri) pada tahun 1951 di Yogyakarta dengan menegerikan fakultas agama Islam pada UII. Di samping itu, pemerintah mendirikan ADIA (Akademi Dinas Ilmu Agama) di Jakarta pada tahun 1957. Hasil perkawinan kelembagaan antara PTAIN dan ADIA diberi nama IAIN (Institut Agama Islam Negeri) atau 'alJâmiah al-Islâmiyah al-Hukûmiyah', didirikan pada tahun 1960 di Yogyakarta. Cabangcabang IAIN di daerah ditingkatkan status oleh pemerintah pada tahun 1997 menjadi STAIN (Sekolah Tinggi Agama Islam Negeri). Pada tahun 2002, dimana IAIN dan STAIN dikonversi menjadi UIN. Setidaknya ada 7 argumentasi yang memotivasi terjadi konversi IAIN dan STAIN menjadi UIN. Tentu, argumentasi ini lahir untuk menge-mukakan aspek-aspek yang melatarbelakangi konversi PTKIN di Indonesia dan melihat perjalanan PTKIN dalam pentas sejarah bangsa Indonesia. Adapun Argumentasi perubahan kelembagaan PTKIN tersebut yakni; politik, sosial-ideologis, kelembagaan, dunia kerja, keilmuan, pembangunan bangsa dan negara, kompetisi global, dan prinsip keterbukaan.

\section{Pustaka Acuan}

Abdullah, Amin. "Religion, Science And Culture: An Integrated, Interconnected Paradigm of Science," dalam al-Jami'ah: Journal of Islamic Studies", Vol. 52, 2014

Ajid, Thohir. Studi Kawasan Dunia Islam PerspektifEtno-Linguistik dan Geo-Politik. Jakarta: Rajawali Pers, 2011.

Al Rasyidin. "Islamic Organizations In North Sumatra: The Politics of Initial Establishment and Later Development," dalam Journal of Indonesian Islam, Vol. 10, 2016.

Azyumardi, Azra. Pendidikan Islam: Tradisi dan Modernisasi di Tengah Tantangan Milinium III, cet. 2. Jakarta: Kencana, 2014.

Badri, Yatim. Sejarah Peradaban Islam. Jakarta: RajaGrafindo Persada, 2003.

Burhanuddin, Jajat. "The Dutch Colonial Policy On Islam: Reading the Intellectual Journey of Snouck Hurgronje," in Al-Jami'ah: Journal of Islamic Studies, Vol. 52, 2014

Hadi, Hasbullah, et al. Kebijakan Pendidikan Nasional Terhadap Pendidikan Islam dan Pendidikan Sekuler,"dalam MIQOT: Jurnal Ilmu-ilmu Keislaman, Vol. XL, 2016.

Haidar, Daulay Putra. Kapita Selekta Pendidikan Islam di Indonesia. Medan: Perdana Publishing, 2012.

Haidar, Daulay Putra. Pendidikan Islam dalam Sistem Pendidikan Nasional di Indonesia. Jakarta: Kencana, 2006.

Hasan Tholhah, Muhammad. Islam dan Masalah Sumber daya Manusia. Jakarta: Lantabora Pers, 2003. 
Hasan, Asari. Esai-Esai Sejarah Pendidikan, dan Kehidupan. Medan: el Misyka Circle, 2009 Hasan, Asari. Menyingkap Zaman Keemasan Islam. Bandung: Citapustaka Media, 2007. Hasan, Asari. Modernisasi Islam: Tokoh, Gagasan dan Gerakan sebuah Catatan tentang Perkembangan Modern Dunia Islam. Bandung: Citapustaka Media, 2002.

Hasibuan, Lias, "Pengembangan Sistem Perkuliahan Kompetensi di Perguruan Tinggi Agama Islam," dalam MIQOT: Jurnal Ilmu-ilmu Keislaman, Vol. XXXII, 2008.

Idris, Muh, "Konsep Pendidikan Humanis dalam Pengembangan Pendidikan Islam," dalam MIQOT: Jurnal Ilmu-ilmu Keislaman, Vol. XXXVIII, 2014.

Lubis, Fadhil Nur A. Rekonstruksi Pendidikan Tinggi Islam: Memberi Makna Kelahiran UINSU. Bandung: Citapustaka Media, 2014.

Mahmud, Yunus. Sejarah Pendidikan Islam di Indonesia. Jakarta: Hidakarya, 1996.

Moh., Roqib. Ilmu Pendidikan Islam: Pengembangan Pendidikan Integratif di Sekolah, Keluarga, dan Masyarakat. Yogyakarta: LKiS, 2009.

Muhaimin. Pemikiran dan Aktualisasi Pengembangan Pendidikan Islam. Jakarta: Rajawali Pres, 2012.

Mulkan, Abdul Munir. "Islamic Education And Da'wah Liberalization: Investigating Kiai Achmad Dachlan's Ideas", dalam al-Jami'ah: Journal of Islamic Studies, Vol. 46, 2008.

Musthofa, Rembangy. Pendidikan Transformatif: Pergulatan Kritis Merumuskan Pendidikan di Tengah Pusaran Arus Globalisasi. Yogyakarta: Teras, 2008.

Muzayyin, Arifin. Kapita selekta Pendidikan Islam. Jakarta: Bumi Aksara, 2007.

Nizar Samsul, et al. Sejarah Sosial dan Dinamika Intelektual Pendidikan Islam di Indonesia. Jakarta: Kencana, 2013.

Noor, Firman. "Islamic Party And Pluralism: The View and Attitude of Masyumi towards Pluralism in Politics (1945-1960)," dalam al-Jami'ah: Journal of Islamic Studies, Vol. 54, 2016.

Qomar, Mujamil. Fajar Baru Islam Indonesia: Kajian KomprehensifAtas Sejrah dan Dinamika Intelektual Nusantara. Bandung: Mizan Pustaka, 2012.

Syahrizal. "Pemikiran Pendidikan Islam Ibn Sahnun: Analisis Kritis Kurikulum Pengajaran di Institusi Pendidikan Dasar Islam," dalam MIQOT: Jurnal Ilmu-ilmu Keislaman, Vol. XXXVI, 2012.

Syamsuddin, Abdullah. Agama dan Masyarakat Pendekatan Sosiologi Agama. Jakarta: Logos Wacana Ilmu, 1997.

Tolchah, Moch. "The Political Dimension of Indonesian Islamic Education in the Post-1998 Reform Period," in Journal of Indonesian Islam, Vol. 08, 2014. 